doi: 10.52370/TISC21281KS

\title{
A NEW CONTEXT AND AESTHETICS OF SERBIAN TRADITIONAL CUISINE IN THE AGE OF PANDEMIC
}

\author{
Katarina Stojanović ${ }^{1}$
}

\begin{abstract}
The new millennium brings new twists, as we are witnessing old becoming new again and cultures and cuisines repeating themselves. Culture has always followed or imposed contemporary challenges. Consequently, food culture also participates in global occurrences, such as the recurrence of economic collapses, health cataclysms, natural disasters, the consequences of climate change, etc. The 2020 global pandemic has indicated that the planet is not going in the right direction. The aim is to observe deeper meanings and paradoxes, predict the consequences and describe the role of new approaches and technologies in the traditional gastronomy of the region on the basis of empirical evidence and a case study for the location of Serbia. The dynamics of experience, authenticity, re-representations in the form of new aesthetics are being examined. New culinologies, as a combination of culinary art and food science, will define the future of food in the age of pandemic and as well as new challenges in general, in order to neutralize them or use their power for the sake of humanity.
\end{abstract}

Key Words: gastronomy, culture, tourism, pandemic, aesthetics JEL classification: Z32, L26, Q13

\section{Introduction}

In addition to global economic pressures and threats to the environment, small European cities are facing various challenges and suffering structural disproportions due to demographic crises of rapidly aging population and labor force going to work in metropolises, as well as facing one of the biggest challenges at present, the coronavirus pandemic.

\footnotetext{
${ }^{1}$ Katarina Stojanović, Associate Professor, Faculty of Hotel Management and Tourism in Vrnjačka Banja, Vojvođanska bb, Vrnjačka Banja; International University of Novi Pazar, Dimitrija Tucovića bb. Novi Pazar, 0631472416, katarina.stojanovic@kg.ac.rs
} 
The lack of "attention to the role of small and medium-sized cities in European sustainable development and underestimation of the role of culture, artistic expression and creativity for integrated development" as a precondition for the sustainability of the city (Hristova et al., 2015, p. 1) neglects the possibility of using their advantages in managing the contemporary crisis.

Application of the content analysis test on the obtained data, that is descriptive analysis, as well as the results of previous research, formulate new ideas and approaches to the future of food culture and tourism in response to the COVID crisis. Low population densities, such as those shown by our ancestors, have a pronounced effect on the transmission of infectious agents, therefore, if the population size is small, it is much more difficult for this to happen (Wolfe, 2011). Consequently, the local community and tourism in general in such areas is similar to the forms of rural tourism, which is a more acceptable solution for today's pandemic context.

Based on the available literature, "factors that will affect tourism and destination recovery are identified" (Hall et al., 2020, p. 577). From a transdisciplinary perspective, we argue that a postpandemic scheme focused on regional, cross-sectoral, and local debate can provide the redirection and benchmarks needed for food sustainability. "In this paper, we propose that the current global crisis provides an opportunity to engage in discussions about how to reconfigure our global food system and that coherent strategies for sustainable development in the future food system need local involvement, cross-sectoral engagement and transdisciplinary expert advice, i.e. decisions should be adapted to reflect local and regional conditions rather than global benchmarks" (Kaiser et al., 2021, p. 2). It is necessary to connect the gastronomic tourism sector with the COVID-19 pandemic, especially in the field of case studies, as a traditional cuisine that can help revitalize tourism, one of the most affected branches of the economy by this pandemic (Garibaldi \& Pozzi, 2020).

The food sector provides examples of the use of technology as a means of creating domestic experiences, when the technology is "practically applied to various sectors of gastronomic tourism, such as food services, places of production and gastronomic events" (Garibaldi \& Pozzi, 2020, p. 2). This aspect of technology has proven to be very powerful in promoting local gastronomy in conditions of pandemic isolation. 


\section{Culture, tourism, gastronomy and sustainability}

"Culture contributes to more sustainable models of city creation which are focused on quality of life, local identities and the creation of places where people like to live". The selected diversity of regionally specific cultural approaches as well as local cultural sectors must be sustainable in order to act as engine of integral development (Hristova et al., 2015, p. 2) and overcoming the crisis caused by the 2020 pandemic.

Culture is based on tradition, providing continuity in tangible and intangible heritage, from the perspective of its contemporary use, reuse and / or adaptation as a "natural" part of the cultural assets of communities and their places. Culture is perceived as a product of historical development, which is created by people and can be destroyed by them. This applies to both tangible and intangible culture. Tangible and intangible cultural heritage intertwine. Culture is integrated into the whole of humanity, technology and society. It is created through a historical process and developed further through the same process. That is why it is dynamic, it transmits artistic, scientific and technical knowledge through generations. In that sense, the events in the 21 st century are significantly influenced by the overall cultural heritage.

The saturation with branded places and symbols is increasingly pronounced, thus opening up the chance to highlight and demand for authentic and different places of branded local character (Stojanović \& Aldag, 2019). The creation of added value in gastronomic tourism is made possible by a series of local food initiatives that try to resolve and support mutual relations arising from the system of primary food production, catering, landscape and tourist attractions (Hjalager \& Richards, 2002).

It is necessary to use new ideas successfully, using innovations and creativity. The role of innovation has certainly been the subject of interest for many years with the tourism industry being the launching site for new technological innovations that have created new markets and products (Álvarez-García et al., 2020). The tourism sector is constantly changing due to its ability to be creative and use new ideas, its sustainability and technological initiatives. Sustainability in tourism most often refers to environmental initiatives, but it also includes resource management in an efficient way. Technology initiatives typically involve the use of new media and internet applications such as social media and artificial intelligence (Álvarez-García et al., 2020). 
"Food culture is an extremely important part of the overall cultural product of an area and many regions of many countries have very recognizable food cultures" (Hegarty \& O'Mahony, 2001, p. 207). The traditional gastronomy associated with a particular place, besides its specificity and uniqueness as an advantage, has ecological and health potential, and some products, due to the way they are produced, their origin or other characteristics can help maintain environmental quality and rural diversity, providing "real benefits to the rural economy and local communities at the same time" (Hjalager \& Richards, 2002, p. 207). As such, they can help the current situation in the time of the coronavirus pandemic and contribute towards restoring the environment and regaining balance in nature, as well as providing an opportunity for social distancing and spending more time in rural or natural surroundings, reducing the inevitable urban contacts, which are an integral part of urban life.

Good food produced in rural communities and from local ingredients, alongside hospitality and service, creates value as part of a rural tourism product (Hegarty \& O'Mahony, 2001). If we want to understand the modern culture of nutrition, and thus our own behaviour, we must look into the recent, but also distant past (Hiršfelder, 2006). Mankind has had to cross the path from raw and unregulated food consumption to the current highly developed food culture, owing to which certain regions of Europe preserve their identity and specialties (Hiršfelder, 2006).

\section{Pandemics, current trends in nutrition and alternatives}

While we continue to hunt, the ways we do it and the methods we use to prepare meat are radically different from the methods used in the past (Wolfe, 2011). In his well-researched book "Lighting a Fire: How Cooking Made Us Humans", Richard Wrangham talks in detail about cooking and its consequences. When our ancestors began to cook extensively, in addition to the benefits that cooking offered them by making food more manageable and enjoyable, they also benefited from its remarkable ability to kill germs (Wolfe, 2011).

Are we going to learn anything from that? "Hegel wrote that the only thing we can learn from history" is that we never learn anything from history and so it is doubtful whether the epidemic will make us wiser, because we have to ask ourselves a key question: What is wrong with our system being caught unprepared for disaster after "scientists warning us about it for years" (Žižek, 2020, p. 11)? Historically, epidemics and pandemics are 
"long-lasting phenomena" that date back to the distant past, and are caused by human and natural factors, because people have always faced epidemics and pandemics which have claimed a huge number of human lives, some of them destroying entire economies and states (Luburić, 2021).

Fruit gathering and hunting, without farming and animal domestication, still exist in some primitive tribes. Consumption of wild food, the source of calories for almost all other organisms on our planet, is now almost an unusual luxury for most people, e.g. wild salmon costs significantly more than farmed salmon (Wolfe, 2011). New ways of aesthetic design show that this type of cuisine can be made very exclusive, modern and innovative and and they can offer a new trend and attractiveness to such a tourist offer, instead of untested collecting nature of finding food and insufficiently researched wilderness.

In the years to come we will face more and more pandemic threats, new pandemics will emerge as we enter deeper into the rainforests and release agents previously unrelated to international transport networks, in short, we will experience a wave of new epidemics, those that will destroy us if we do not learn to predict and control them in a better way. That is why we must be very careful with this new trend in nutrition. Taking virology into account and using exotic food under professional control, care and analysis is pivotal. It would be the safest to use past experiences and consider cooking and domestication to be the heritage of humanity without thinking that we are much smarter now.

By using a variety of strategies, they simultaneously counteract trends, often mitigating the socio-ecological destructive effects of neoliberal processes (Roy, 2011, p. 87). Due to the imbalance that exists between countries in relation to the levels of national environment control, the rich nations, which have relatively strict ecological legislation, export their hazardous waste to the poorer countries, in which the ecological legislation is relatively weak (Stojanović \& Lošonc, 2017). "Scientific teams can highlight ethical considerations in local and natural resource management. The pandemic has exposed several sustainable and ethical challenges to the food system" (Kaiser et al., 2021, p. 4). Prerequisites for any cultural and economic business today are above all: creativity, innovation and risk (Hartley, 2007).

A thoughtful "framework for food systems would include these key elements" (Kaiser et al., 2021, p. 4): 
1. Intersectoral, cross-cultural conversations and cooperation open to plural worldviews and values with ethical considerations of how to restructure the food system.

2. Find global benchmarks, but contextualized for specific regions. Look for custom options for specific target systems.

3. Assistance of science in transdisciplinary approach and scientific education for the purpose of social benefit. A transdisciplinary research approach can respond to the demands of dynamic spatial and cultural transformations and encourage the development of collaborative knowledge in various forms of action, from education, science, to professional action (Perović, 2016).

4. Use new approaches and innovations, creativity and technology in promoting tradition and authenticity, as motivators for accepting the "new normality", when global food trade is threatened by increased unpredictability and instability of financial markets, then when consumer dining patterns have moved to domestic cuisine and food "during the pandemic while restaurants and schools were closed, but it remains to be seen whether lasting trends in consumer food preferences will emerge in the post-pandemic era" (Kaiser et al., 2021, p. 3).

5 . The need for "government to carefully combine governmental and nongovernmental interventions in reducing food insecurity was emphasized" (Mishra \& Rampal, 2020, p. 1).

6. Approach food systems in the context of the impact of a pandemic, because the facts are uncertain, the values are disputed, the stakes are high and decisions are urgent.

7. The explicit inclusion of scientific as well as social "uncertainties inherent in the plurality of values is crucial for this endeavor" (Kaiser et al., 2021, p. 2).

\section{Tradition, local and repetition of the past}

"Food, cuisine and culinary traditions are among the most important elements of culture, although there is a long tradition of identifying many places with their traditional food, cuisine is becoming an increasingly important part of contemporary cultural heritage" (Timothy \& Ron, 2013, p. 2), in Serbia just as in other countries. Not only does food complement other elements of the cultural environment, but cuisine and food routes are themselves an important part of heritage because they reflect cultural norms and values and the physical reality of geography and places. They are part of intergenerational legacy and leave a mark "on other elements of human 
heritage (e.g. religion, language, politics and power, agricultural landscapes and family relations)" (Timothy \& Ron, 2013, p. 2).

"Native foods and their endemic ingredients, as well as the peasant or colonial origins of many popular foods today, contribute substantially to creating the identity of nations and peoples, and traditional cuisines can help preserve identity among diaspora groups and strengthen national solidarity". From a place promotion perspective, heritage cuisines can also help "branded" destinations (Timothy \& Ron, 2013, p. 3). Initiatives "seek to facilitate such integration by developing local gastronomy", using local products to increase the area's attractiveness to visitors (Hjalager \& Richards, 2002, p. 91).

People are constantly inventing and repeating their cuisines and cultures. Buffalo and ostrich meat, which used to be consumed in the Stone Age, is sold in supermarkets. Pomegranate juice, which was used in the Middle East 5,000 years ago, is sold as a powerful antioxidant health drink. Roman-era privileged foods have also been returned to widespread use; truffles, chocolate, caviar, wine or unripe grape juice, popular since the Middle Ages and commercially produced as a wine alternative to vinegar, then edible gold, the Aztec spirulina is now sold in healthy food shops, sweet and sour sauce is a combination from the Middle Ages, ice cream cones are now made as a salty cone for salmon tartare, etc. (Civitello, 2008, p. 361).

Ethnic food and ethnic restaurants persist in their own regional dishes to which people are accustomed, which are charged with symbolic value. The "future of food lies in preserving its past, and while some plants are grown in increasing numbers, hundreds of species become extinct each year", which is an ecological catastrophe, because we don't know what new food or medicine those plants which have disappeared forever could have become. As a result, there are more and more seed and cell stores. However, apart from "sustainable agriculture, sustainable livestock and fish are also important for the future of food" (Civitello, 2008, p. 363).

\section{Aesthetics of gastronomy and new approaches to food as art and creativity}

Gastronomy, "selection, preparation, presentation and participation with culinary and gastronomic aspects of food" belongs to the category of "fine arts", because most societies try to differentiate their food preparation into 
purely useful or highly useful, developed and stylized methods of presentation and participation, which are in many cases designed not only for consumption, but also for status, ritual and aesthetic purposes (Hegarty \& O’Mahony, 2001, p. 3).

In public discourses especially, aesthetic issues are often seen as something that relates exclusively to the appearance of things. Aesthetics, in fact, implies the exterior and the way it affects our senses, and aesthetic values are often associated with a sense of satisfaction. However, aesthetics is not limited to the external qualities of the objects around us. There is also the so-called deeper aesthetics, which constitutes a true aesthetic quality of life (Morgan et al., 2015, p. 147).

No element of the composition has its own consistency or meaning, it acquires them in relation to others. The symbolic scheme of heaven-manearth is only an extremely clear and successful formula to point out this absence of autonomy that marks every element, but also every cosmic situation and state of life. The types of foods used best show their own transient and volatile character, which inevitably marks every material, physical or mental (Paskvaloto, 2006).

This character on the plate cannot be understood in the sense of "mortality", because this term, at least for most of our western tradition, hides the idea of loss and the feeling of melancholy. They appear as signs of disappointment in relation to the illusion of duration, which is often imagined as eternity. Here, on the other hand, we are in the domain of meaning in which we are aware that the only real state is instability. Therefore, the composition is not a concentrated manifestation, an aesthetically efficient distillate of that universal instability (Paskvaloto, 2006).

Gastronomy is interpreted as an art form, indicating the ubiquity of art and that any human activity, if performed "with sufficient skill, can be the subject of art" (Hegarty \& O'Mahony, 2001, p. 12). In Ancient Greece, the word "beautiful" had a much broader meaning than today and it used to represent shapes, colors, thoughts and customs. Today, the fact is that all art, including the one based on food, must give birth to beauty.

Today's gastronomic menu is recognized by gastronomic regions; for example, the Pannonian gastronomic region in Vojvodina is recognized for being considerably influenced by European culture. According to research, 
the western and central gastronomic regions are mixed with the Central Balkan and Dinaric gastronomic regions, the south and east of Serbia being even more authentic, where much of the Old Balkan cultural heritage in terms of nutrition is preserved (Stojanović \& Đenadić, 2020).

The concept of Culinary Science - a combination of culinary art and food science - was introduced in 1996 by the Association of Research Chefs, which quickly changed the way the American food industry developed new food products (Hegarty, 2006). "For gastronomy, this translates into menu balance and harmony in areas such as colour, temperature, taste and texture, which in some cases can be determined by the aesthetic requirements of the raw materials used to create a gastronomic piece" (Hegarty \& O'Mahony, 2001, p. 12).

\section{Serbian and European traditional cuisine}

The gastronomic characteristics of the European continent are very different, but some similarities can be noticed (Vojnović \& Cvijanović, 2017). Western Balkan countries "have already recognized the potential of gastronomy as an experience for tourists and started to educate tourists and promote local food" (Čavić et al., 2020, p. 1283). The gastronomies of the world often have great overlaps, which were created by long-term influences, such as colonisation and the like. However, every gastronomy has managed to preserve something authentic. Serbian gastronomy has been influenced by many different countries, via long-term occupation or as a result of its multinationality. The diversity of Serbian cuisine has also been affected. It should be noted and pointed out that boundaries in gastronomy and cuisine are not clearly outlined, so there are no clear rules. The proof is the cuisine of our province of Vojvodina, which is characterized by the Hungarian type, while in another province, the cuisine is characterised by the oriental type and the like. It is characterised by strong spices, spicy and chilly flavours, the use of peppers (vegetables) and black pepper.

Of all these foods, some old Serbian food preparation technologies are on the list of Serbia's intangible cultural heritage:

1. Belmuž (traditional sheperd dish made from unripened cheese), proposed by Municipality of Knjaževac, in cooperation with Knjaževac Homeland Museum, Local Office in Kalna and Association for the Preservation of Tradition "Izvor" from Knjaževac 
2. Production of Pirot hard cheese, proposed by Municipality of Pirot, in cooperation with Ponišavlje Museum in Pirot

3. Mantija (Pazar meat pie prepared in a traditional way), proposed by the City of Novi Pazar, in cooperation with Ras Museum in Novi Pazar and the Cultural Centre Novi Pazar

4. Rakija (plum brandy), proposed by National Museum in Čačak

5. Kajmak making knowledge and skills, proposed by Open-air Museum "Staro selo" in Sirogojno and National Museum in Čačak

6. Cipovka - knowledge and skills in preparing traditional bread in Vojvodina, proposed by Balkankult Foundation from Irig and Mlinpek Institute from Novi Sad

7. Cooking žmare (made from mutton, corn flour and leek), proposed by Municipality of Petrovac na Mlavi and Homeland Museum Petrovac na Mlavi.

Having all the characteristics in mind, a brand could be formed by combining them with a modern approach, avoiding the use of risky food sources during the pandemic.

\section{Results}

This chapter attempts to provide evidence of technological application in the current pandemic crisis impact scenario, paying attention to the gastronomic tourism experience (Garibaldi \& Pozzi, 2020, p. 1). It is concluded that the selective nature of the effects of COVID-19 and measures to combat it may in some cases lead to a reorientation of tourism, but in others it will contribute to policies that reflect the selfish nationalism of some countries. However, responding to planetary constraints and sustainable tourism requires a global approach. Despite clear evidence of this necessity, the possibility of a comprehensive transformation of the tourist system remains extremely limited without a fundamental transformation of the entire planet (Hall et al., 2020; Žižek, 2020).

To prepare for an uncertain future, we must make the best assumptions based on the present, and for post-pandemic times, three possible future food scenarios can be predicted:

1. The situation before the pandemic will return after the end of the crisis.

2. Existing trends will accelerate and the foreseeable future will be achieved.

3 . The "new normalcy" will burst from the past and will radically reset most of society (Kaiser et al., 2021, p. 12). 
For the third prediction point, it is possible to suggest some new models, based on which this riset will be easier to accept.

Gastronomy represents a combination of food, art, pleasure, taste and science, while the experience of the culture to which food belongs also directs people to particular rural areas, regions and countries due to which food becomes an essential attraction for tourism (Polat \& Aktaş-Polat, 2020, p. 243).

Levi-Strauss's research in structuralism resulted in a culinary triangle which, through analogy, uses food and cooking as a language in order to understand society, whereas Polat and Aktaş-Polat (2020) transform this triangle into a "new culinary triangle in gastronomic tourism in the context of cultural and artistic transformation" (p. 245).

Figure 1: The new culinary triangle as an opportunity for Serbian traditional cuisine in a new context, according to The Culinary Triangle in Gastronomy Tourism by (Polat \& Aktaş-Polat, 2020).

\section{LOKAL}

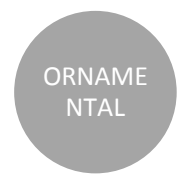

Source: Author

The idea of this research is to use the results acquired so far and apply this new triangle to Serbian traditional cuisine in order to maintain its sustainability even within the global pandemic crisis in 2020 .

Local cuisine, in this case Serbian, can be combined with tastes from other cultures, in which case it becomes a hybrid, whereas applying art and aesthetics can create decorative cuisine, where one should be careful not to slide into kitsch. The first precondition has already been fulfilled, by concluding on the basis of the previous chapter that the Serbian traditional 
kitchen has been influenced by many different countries, i.e. different food cultures. The second precondition can be achieved through science and art, i.e. technology and new aesthetics.

Technology certainly provides new opportunities, not only in making it easier for tourists to access information but also in creating new experiences from home (Garibaldi \& Pozzi, 2020, p. 1). "Online cooking sessions and tutorials, live tastings, virtual reality tours, remote social eating and drinking are current and sustainable applications that have managed to support and temporarily replace the traditional gastronomic tourism experience" (Garibaldi \& Pozzi, 2020, p. 1), which is currently denied due to the pandemic. These are all areas that imply creativity and new aesthetics in order to attract consumers, their attention, and that virtual aesthetic is different from the one required live. New experiences and attracting attention, certainly come from the authentic, unknown, original, which traditional cuisines are, and this is evidenced by many studies (Apaduraj, 2013; Morgan et al., 2015, Rot, 2012).

Brillat-Savarin treated gastronomy as a science and defined it as a phenomenon that combines food with art (Polat \& Aktaş-Polat, 2020, p. 244). The culinary study program includes elements from culinary art and food science, enabling the student to understand the science behind food while mastering culinary art. As a new academic discipline, culinary science will revolutionize the food industry and its experts will define the future of food in a pandemic and new challenges (Hegarty, 2006).

Gastronomic tourism acts as a bridge between the past and the future, protecting a living culinary culture and passing it on to future generations, and local culinary cuisine consists of food and drinks "specific to a particular area, region or country" (Polat \& Aktaş-Polat, 2020, p. 248). Stereotypes related to the culture of nutrition can be found in everyday language, common phrases and jokes, literature and the world of imagination of a nation. Different ethnic, regional, national or religious groups are often categorized and separated by food, i.e. specific food culture.

Local cuisine preserves its roots through local flavors. The "demand for rural and natural products has increased in the kitchen due to the poor effect of industrial production" (Polat \& Aktaş-Polat, 2020, p. 248), and is now an alternative in the pandemic crisis. It contributes to the existence of 
cultural elements in everyday life and the creation of authenticity and identity.

Hybrid culinary food combines new experiences and transforms local culinary arts, while decorative cuisine, via combining science and art, offers tourists food as an element of social status. The fact that gastronomic tourism is maintained on the basis of artistic and cultural transformation makes it important to preserve and maintain local cuisine and pass it on to future generations (Polat \& Aktaş-Polat, 2020, p. 252).

Innovations could also have a permanent impact on gastronomic tourism. First, it involves a reversal in "thinking away from product or service towards a more holistic approach to the entire experience" that also takes into account how "technology can transform tourism service ecosystems. With the technology that has the potential to enable dynamic real and virtual co-creation process, gastronomy tourism suppliers should be stimulated to include travellers into the process of experience design and development" (Garibaldi \& Pozzi, 2020, p. 4), which makes an important link in bridging the current problem in gastronomic tourism caused by the inability to travel due to the COVID-19 pandemic.

\section{Strategies and local development}

In this paper, we have collected entry points for dialogue to re-imagine and restructure food systems in postpandemic times. "This will require transdisciplinary science in empirical study" (Kaiser et al., 2021, p. 14). The separation of the local and tourism, culture and economy, food and lifestyle are beginning to produce new hybrid forms of gastronomic experience, jointly created by food communities, which results in the development of creative tourism and holistic food policies of different destinations, requiring an increasing degree of multidisciplinary and transdisciplinary work in the future (Richards, 2015, p. 11).

Cittasl's concept plays an important role in cities acquiring their own identities, branding and achieving advantages in the local development and it is based on three principles of (Özden at al., 2017):

"Good: The taste and aroma of food, recognizable by educated, welltrained senses, are the fruit of the producers' competence and the choice of raw materials and production methods which should in no way change its naturalness" (Cheng et al., 2011, p. 17). 
"Clean: The environment must be respected and sustainable disarmament, livestock, processing, marketing and consumption practices must be seriously considered" (Cheng et al., 2011, p. 17). Each phase of the agroindustrial production chain, including consumption, should simultaneously protect ecosystems and biodiversity and the health of consumers and producers.

"Fair: Social justice should be sought by creating working conditions that respect human rights and that can create appropriate rewards, through the pursuit of balanced global economies, practice of sympathy and solidarity, and respect for cultural differences and traditions" (Cheng et al., 2011, p. 17).

\section{Conclusion}

The radical transformation of existing food systems emphasizes the need to recognize the truly pervasive insecurities and differences in values and cultures of food knowledge, which makes a universal vision of future food systems an illusion. Transparent debates are already taking place in some advanced parts of the world, "which mobilize diverse actors at local, regional and national levels" (Kaiser et al., 2021, p. 14). The sciences need to approach to a transdisciplinary mode of action in order to be a truly constructive partner in these considerations. It is suggested that in addition to science, creativity should be used in reorientation, in a way that is presented in detail in the paper, because it is currently a crucial source of advantage in a market (Hartley, 2007).

From the earliest times, "rules have combined with traditions, customs, religious beliefs, morals and ceremonies", in accordance with their own structure and value judgments, in accordance with the structures and values of societies, resulting in societies' own diets and culinary cultures" (Kiliç et al., 2017, p. 140). Geographical and climatic diversity, the influence of the Byzantine and Oriental culture and the European gastronomic heritage have significantly diversified the culinary culture of the Serbian society.

During this age of pandemic when we are isolated, closed in our communities, turning to the traditional national cuisine certainly contributes to cutting contacts around the world. This attitude seems contrary to cosmopolitanism, however, "cultural diversity is the common heritage of humanity". (Šobe \& Marten, 2014). 
It is important to nurture taste by encouraging progress and international exchange programs, "by supporting valuable projects, advocating historical food culture and defending old-fashioned food traditions" (Özden et al., 2017, p. 183). We can contribute to the preservation of Serbian traditional cuisine and help overcome the risk of the crisis caused by the pandemic.

This concept offers an alternative way against everyday sensory experiences and global capitalist consumption. Within this perspective, the Cittaslov concept supports local business which reveals that concepts such as fair trade, local trade and the agricultural market have been brought to the forefront. The slow movement of food has been cited as an ideological platform for a civic by-product which constitutes local codes of practice related to uninhabitability and quality of life (Özden et al., 2017).

\section{References}

1. Álvarez-García, J., Braga, V., Ratten, V. (2020). Tourism innovation: technology, sustainability and creativity, Routledge, London.

2. Apaduraj, A. (2011). Kultura i globalizacija, Biblioteka XX vek, Beograd.

3. Čavić, D., Radojković, M., Vujanović, M. (2020). Innovative Food Products as a Basis for the Development of Rural Tourism in Vojvodina. Economics of Agriculture, Vol. 67, No. 4, 1283-1295.

4. Cheng, M., Ogbeide, G.-C. A., Hamouz, F. L. (2011). The Development of Culinary Arts and Food Science Into a New Academic DisciplineCulinology. Journal of Culinary Science \& Technology, Vol. 9, 17-26.

5. Civitello, L. (2008). Cuisine and Culture: A History of Food and People, John Wiley \& Sons.

6. Garibaldi, R., Pozzi, A. (2020). Gastronomy tourism and Covid-19: technologies for overcoming current and future restrictions, in book: Tourism Facing a Pandemic: From Crisis to Recovery. Università degli Studi di Bergamo.

7. Hall, C. M., Scott, D., Gössling, S. (2020). Pandemics, transformations and tourism: be careful what you wish for. Tourism Geographies, Vol. 22, No. 3, 577-598. 
8. Hapala, A. (2009). The aesthetic quality of life. The Future of Aesthetics Annual Conference of the Nordic Society for Aesthetics, Trondheim.

9. Hegarty, J. A. (2006). Developing "subject fields" in culinary arts, science, and gastronomy. Journal of Culinary Science \& Technology, Vol. 4, No. 1, 5-13.

10. Hegarty, J. A., O’Mahony, G. B. (2001). Gastronomy: A phenomenon of cultural expressionism and an aesthetic for living. International Journal of Hospitality Management, Vol. 20, No. 1, 3-13.

11. Hiršfelder, G., (2006). Evropska kultura hrane: Povest ishrane od kamenog doba do danas =[European food culture: The history of nutrition from the Stone Age to the present day], Stylos, Novi Sad,

12. Hjalager, A.-M., Richards, G. (Eds.) (2002). Tourism and Gastronomy, Routledge, London.

13. Hristova, S., Dragićević Šešić, M., Duxbury, N. (edc.). (2015). Culture and Sustainability in European Cities Imagining Europolis, Routledge Taylor \& Francis Group, New York.

14. Kaiser, M., Goldson, S., Buklijas, T. et al. (2021). Towards PostPandemic Sustainable and Ethical Food Systems. Food ethics, Vol. 6, No. 1, 1-19.

15. Kiliç, G., Yüceda, N., Aytek, E. (2017). A General Evaluation on Hittite and Phrygiancuisine Culture. 3rd International Gastronomic Toursim Congress, Izmir, Proceedings, 140-156.

16. Luburić, R. (2021). Crisis Prevention and the Coronavirus Pandemic as a Global and Total Risk of Our Time. Journal of Central Banking Theory and Practice, Vol. 10, No. 1, 55-74.

17. Mishra, K., Rampal, J. (2020). The COVID-19 pandemic and food insecurity: A viewpoint on India. World Development, 135: 105068.

18. Morgan, N., Pričard, A., Prajd, R. (2015). Destinacija kao brend, Clio, Beograd. 
19. Özden, O., Sünnetçio, S., Özkök, F. (2017). 'Cittaslow' and 'Slow Food' in the Eyes of Food and Beverage Business Managers: Gökçeada Sample. 3rd International Gastronomic Toursim Congress, Izmir, Proceedings, 181-195.

20. Paskvaloto, Đ. (2006). Estetika praznine, [Aesthetics of emptiness], Clio, Belgrade.

21. Perović, S. (2014). Transdisciplinarna istraživačka paradigm u razvoju održive fizičke strukture grada, [=Transdisciplinary research paradigm in the development of sustainable physical structure of the city], University of Novi Sad, Faculty of Technical Sciences, Novi Sad.

22. Polat, S., Aktaş-Polat, S. (2020). Transformation of Local Culinary through Gastronomy Tourism. Sosyoekonomi, Vol. 28, No. 43, 243-256.

23. Richards, G. (2015) Gastronomic experiences: From foodies to foodscapes. Journal of Gastronomy and Tourism, Vol. 1, 5-18.

24. Rot, K. (2012). Od socijalizma do Evropske Unije [=From Socialism to the European Union], XX Century Library, Belgrade.

25. Roy, P. (2011). Non-profit and community-based green space production in Milwaukee: Maintaining a counter-weight within neo-liberal urban environmental governance. Space and Polity, Vol. 15, No. 2, 87105.

26. Šobe, F., Marten, L. (2014). Međunarodni kulturni odnosi [=International cultural relations]. Clio, Belgrade.

27. Stojanović, K. Aldag, M. Č. (2019). New Cultural Meanings Embedded in the City by Means of Transnational Capital. 5th international Scientific Conference 'Corporations as Multidimensional Actors/Entities', Muzej Vojvodine, Faculty of technical sciences, Novi Sad.

28. Stojanović, K., Đenadić, M. (2020). Cultural Tourism and Folk Architecture in the Service of Revitalization of Rural Space, "Tourism in Function of Development of the Republic of Serbia-Tourism and Rural Development", Faculty of Hotel Management and Tourism in Vrnjačka Banja, University of Kragujevac, Vrnjačka Banja. 
29. Stojanović, K., Lošonc, A., (2017). Impact of Financialization in Transformation of Urban Environment and Example of Settlement Detelinara in Novi Sad. Facta Universitatis, Series: Architecture and Civil Engineering, Vol. 15, No. 3, 387-402.

30. Timothy, D. J., Ron, A. S. (2013). Understanding heritage cuisines and tourism: Identity, image, authenticity, and change. Journal of Heritage Tourism, Vol. 8, No. (2-3), 99-104.

31. Vojnović, B., Cvijanović, D. (2017). Menadžment gastronomije $i$ restoraterstva, Fakultet za hotelijerstvo i turizam, Vrnjačka Banja.

32. Wolfe, N. (2011). The Viral Storm The Dawn of a New Pandemic Age, Times Books, New York.

33. Žižek, S. (2020). PANDEMIC COVID-19 Shakes the World, OR Books, New York and London. 